Jurnal Ilmu-Ilmu Peternakan 25 (2): 1 - 9

ISSN: 0852-3581

E-ISSN: 9772443D76DD3

CFakultas Peternakan UB, http://jiip.ub.ac.id/

\title{
Pengaruh penambahan betain dalam pakan rendah metionin terhadap kualitas karkas itik Mojosari jantan
}

\author{
Masayu Putri P, Eko Widodo dan Osfar Sjofjan \\ Fakultas Peternakan Universitas Brawijaya Malang \\ Jl. Veteran Malang 65145 Jawa Timur \\ masayu_p@yahoo.co.id
}

\begin{abstract}
The objective of this research was to observe the effect of betaine in feed to carcass, breast meat, thigh meat, abdominal fat, and meat cholesterol in Mojosari male ducks. The materials of this experiment were 144 male ducks which were maintained for 8 weeks. P0 was control treatment with no betaine were added, whereas $\mathrm{P} 10.1 \%, \mathrm{P} 20.2 \%, \mathrm{P} 30.3 \%$ of betaine addition in the feed. The method used in this research was field experiments with 4 treatments and 6 replications. The parameters that measured in this research were carcass percentage, percentage of breast and thigh meat, abdominal fat, and breast cholesterol. Data were tabulated into MS. Excel and analyzed using ANOVA of Completely Randomized Design (CRD). If there were significant differences among the treatments, it will be tested by Duncan's Multiple Range Test. The result showed that addition of betaine had a significant effect $(\mathrm{P}<0.05)$ on carcass percentage, percentage of breast and thigh meat, but it didn't has a significant effect $(\mathrm{P}>0.05)$ on cholesterol of breast meat and abdominal fat. The use of betaine in low methionine feed could improve carcass percentage, percentage of breast and thigh meat deposition, and lower abdominal fat percentage, but it has no effect on the cholesterol content of breast meat in Mojosari male ducks. The research concluded that $0.3 \%$ of betaine administration on feed was the best result for Mojosari male duck carcass quality, in terms of carcass percentage, the percentage of breast meat and thigh, and lower abdominal fat percentage.
\end{abstract}

Keywords : Betaine, addition, low metionin, carcass, Mojosari duck

\section{PENDAHULUAN}

Itik Mojosari jantan digunakan sebagai salah satu alternatif itik pedaging atau itik potong karena bobot dewasanya bisa mencapai 1,4-1,7 kg/ekor. Secara umum itik jantan merupakan beban bagi peternak karena tidak bisa memproduksi telur konsumsi kecuali sebagai pemacek untuk menghasilkan telur tetas yang fertil. Berbagai upaya telah dilakukan untuk memanfaatkan itik jantan yang diproduksi sebagai itik potong.

Menurut Anggorodi (1995),
unggas tidak mampu mensintesis
beberapa asam amino yang diperlukan
untuk pembentukan protein bagi tubuh
sehingga harus disediakan dalam pakan.
Asam amino non-esensial dapat dibentuk
dari asam amino esensial atau dari
sumber-sumber nitrogen non-protein.
Protein pada jaringan tubuh unggas dan
telur mengandung lebih banyak asam
amino esensial tertentu dari pada yang
terdapat dalam protein pakan. Asam


amino tersebut dinamakan asam amino esensial kritis dan sering kali jumlahnya tidak cukup dalam pakan. Asam amino esensial lainnya disebut asam aminno esensial non-kritis karena sebagian besar pakan mengandung zat-zat tersebut dalam jumlah yang cukup untuk memenuhi kebutuhan unggas.

Dua dari asam amino esensial kritis yaitu metionin dan lisin dapat diperoleh dalam bentuk sintesis, sehingga kekurangan zat-zat tersebut dapat diatasi dalam penyusunan pakan. Produksi itik Mojosari jantan dapat ditingkatkan sebagai itik pedaging dengan pemberian suplemen tambahan dalam pakan berupa metionin. Selain itu, metionin bisa didapatkan dari donor gugus metil yaitu betain yang dapat meningkatkan kualitas karkas dan termasuk sebagai osmolit yang mempengaruhi struktur usus dan organ pencernaan didalam tubuh itik tersebut. Ratriyanto, dkk (2012) menyatakan bahwa kesamaan peran antara betain dan metionin sebagai donor gugus metil menyebabkan betain berpotensi menggantikan peran metionin, sehingga metionin lebih banyak digunakan untuk sintesis protein dan menghasilkan pertumbuhan ternak yang optimal serta kebutuhan metionin dalam pakan dapat diturunkan. Secara ekonomis, penggunaan betain untuk menggantikan metionin dapat menghemat biaya pakan.

\section{MATERI DAN METODE}

Penelitian ini menggunakan 144 ekor DOD Mojosari jantan yang dipelihara selama 8 minggu dan memiliki bobot rata-rata 42,92 g/ekor dengan koefisien keragaman $6,05 \%$.

Pemberian pakan dan minum diberikan secara ad libitum. Bahan pakan yang digunakan dalam penelitian ini adalah jagung, bungkil kedelai, tepung ikan, minyak kelapa, premix, garam dan kapur. Kandungan zat nutrisi bahan pakan perlakuan dapat dilihat pada Tabel 1. Sedangkan susunan bahan pakan perlakuan dan kandungan zat makanan basal dapat dilihat pada Tabel 2.

Tabel 1. Kandungan zat nutrisi bahan pakan perlakuan

\begin{tabular}{|c|c|c|c|c|c|c|c|c|}
\hline \multirow[b]{2}{*}{ Bahan pakan } & \multicolumn{8}{|c|}{ Kandungan zat makanan } \\
\hline & $\mathrm{ME} \mathrm{Kkal} / \mathrm{kg}$ & $\begin{array}{l}\text { PK } \\
(\%)\end{array}$ & $\begin{array}{l}\text { SK } \\
(\%)\end{array}$ & $\begin{array}{l}\mathrm{LK} \\
(\%)\end{array}$ & $\begin{array}{l}\mathrm{Ca} \\
(\%)\end{array}$ & $\begin{array}{c}\mathrm{P} \\
(\%)\end{array}$ & $\begin{array}{l}\text { Lis } \\
(\%)\end{array}$ & $\begin{array}{l}\text { Met } \\
(\%)\end{array}$ \\
\hline Jagung kuning & 3370 & 8,6 & 2 & 3,9 & 0,02 & 0,1 & 0 & 0,18 \\
\hline Pollard & 1300 & 15 & 10 & 4 & 0,14 & 0,32 & 0 & 0 \\
\hline Bungkil kedelai & 2240 & 45 & 6 & 0,9 & 0,32 & 0,29 & 0,24 & 0,2 \\
\hline Minyak kelapa & 8600 & 0 & 0 & 100 & 0 & 0 & 0,64 & 0,29 \\
\hline Tepung ikan lokal & 3000 & 40 & 4 & 4 & 4 & 1,8 & 5,2 & 1,5 \\
\hline Kapur & 0 & 0 & 0 & 0 & 38 & 0 & 0 & 0 \\
\hline garam & 0 & 0 & 0 & 0 & 0 & 0 & 0 & 0 \\
\hline Premix* & 0 & 0 & 0 & 0 & 25 & 0 & 0 & 0 \\
\hline
\end{tabular}

Keterangan : *Rhisomix LC mengandung Vitamin A: 8.000.000 IU; Vitamin $\mathrm{D}_{3}: 1.600 .000$ IU; Vitamin $\mathrm{E}: 16.000 \mathrm{mg}$; Vitamin $\mathrm{K}_{3}: 5.000 \mathrm{mg}$; Vitamin $\mathrm{B}_{1}: 2.000 \mathrm{mg}$; Vitamin $\mathrm{B}_{2}: 4.000 \mathrm{mg}$; Vitamin $\mathrm{B}_{6}: 2.000 \mathrm{mg}$, Vitamin $\mathrm{B}_{12}: 100 \mathrm{mg}$; Vitamin $\mathrm{C}$ : $10.000 \mathrm{mg}$, Ca-d pantothenate $: 10.000 \mathrm{mg}$, Nicotinic acid:40.000 mg; Folic acid:3.000 mg; Choline chloride: $120.000 \mathrm{mg}$; Lysine:80.000 mg; Methionine:100.000 mg; Egg Promotant:20.000 mg; Mangan (Mn):40.000 mg; Zinc (Zn):30.000 mg; Ferrouse (Fe):40.500 mg; Copper (Cu):25.000 mg; Cobalt (Co):8.000 mg; Iodate (I):1.250 mg; Selenium (Se):150 mg; Calcium powder: $1.000 \mathrm{~g}$. 
Tabel 2. Susunan bahan pakan dan kandungan zat pakan basal

\begin{tabular}{|c|c|c|}
\hline Bahan pakan & Persentase $(\%)$ & \\
\hline Jagung kuning & 46,674 & \\
\hline Pollard & 23,337 & \\
\hline Bungkil kedelai & 15,558 & \\
\hline Minyak kelapa & 3,5 & \\
\hline Tepung ikan lokal & 9,335 & \\
\hline Kapur & 0,233 & \\
\hline Garam & 1,322 & \\
\hline Premix & 0,039 & \\
\hline Total & 100 & \\
\hline Kandungan zat makanan & Hasil perhitungan & Hasil analisis * \\
\hline Bahan kering (\%) & - & 87,46 \\
\hline Energi metabolis (Kkal/kg) & 2805,91 & $2684 * *$ \\
\hline Protein kasar $(\%)$ & 18,25 & 20,93 \\
\hline Serat kasar (\%) & 4,57 & 3,87 \\
\hline Lemak kasar (\%) & 6,77 & 6,18 \\
\hline Abu $(\%)$ & - & 11,98 \\
\hline $\mathrm{Ca}(\%)$ & 1,03 & - \\
\hline $\mathrm{P}(\%)$ & 0,33 & - \\
\hline Metionin (\%) & 0,27 & - \\
\hline Lisin $(\%)$ & 0,64 & - \\
\hline
\end{tabular}

Keterangan : *Laboratorium Nutrisi dan Makanan Ternak Fakultas Peternakan Universitas Brawijaya, Malang

**Dihitung 70\% dari Gross Energy (Schable, 2004)

Kandang yang digunakan dalam penelitian adalah kandang litter dengan luas $12 \mathrm{~m}$ x $4 \mathrm{~m}$ dan setiap plot luasnya $1 \mathrm{~m} \times 1,5 \mathrm{~m} \times 50 \mathrm{~cm}$ dengan total 24 plot. Setiap plot kandang diisi 6 ekor itik. Metode yang digunakan adalah percobaan lapang menggunakan Rancangan Acak Lengkap (RAL) dengan 4 perlakuan dan 6 ulangan. Masing-masing ulangan terdiri dari 6 ekor itik. Perlakuan dalam penelitian ini adalah sebagai berikut.

P0: Pakan basal tanpa perlakuan

P1: Pakan basal + Betain level 0,1\%

P2: Pakan basal + Betain level 0,2\%

P3: Pakan basal + Betain level 0,3\%

Variabel penelitian yang diteliti antar lain bobot karkas dan persentase karkas, persentase lemak abdominal, bobot dada dan paha serta kolesterol daging.

\section{Bobot karkas dan persentase karkas}

Data bobot karkas diperoleh dengan cara menimbang bobot karkas dengan timbangan digital. Penimbangan dilakukan pada akhir penelitian pada umur 8 minggu. Bobot karkas dihitung dengan cara menimbang tubuh itik yang telah dipotong pada umur 6 minggu dikurangi bobot darah, bulu, kepala, kaki dan organ dalam/visceral (Sumiati dkk, 2005). Persentase karkas dihitung pada ternak itik berumur 8 minggu yang telah dipotong. Perhitungan persentase karkas adalah sebagai berikut :

$\%$ karkas $=\frac{\text { bobotkarkas }}{\text { bobot hidup }} \times 100 \%$

\section{Persentase lemak abdominal}

Lemak abdominal merupakan lemak yang terdapat pada sekeliling gizzard dan lapisan yang menempel 
antara otot abdominal dan usus. Persentase lemak abdominal diperoleh dengan cara membagi bobot lemak abdominal dengan bobot potong dikalikan 100\% (Widiastuti, 2001). Pengambilan data persentase lemak abdominal dilakukan pada minggu ke-8 dengan cara mengambil lemak bagian rongga perut pada itik Mojosari jantan, kemudian ditimbang dan dihitung menggunakan rumus sebagai berikut:

$\%$ karkas $=\frac{\text { bobotlemakabdominal }(\mathrm{g})}{\text { bobothidup }(\mathrm{g})} \times 100 \%$

\section{Bobot dada dan paha}

Pengambilan data untuk bobot dada dan paha itik Mojosari jantan dilakukan pada umur 8 minggu yang telah dipotong kemudian diambil bagian dada tanpa tulang dan paha kemudian ditimbang dan dihitung menggunakan rumus sebagai berikut:

$\%$ Dada $/$ Paha $=\frac{\text { bobotdada } / \mathrm{paha}(\mathrm{g})}{\text { bobothidup }(\mathrm{g})} \times 100 \%$

\section{Kolesterol daging}

Pengujian kandungan kolesterol daging dilakukan dengan mengambil dada yang telah di fillet (tanpa tulang) dan ditimbang, kemudian dianalisa di Laboratorium Biokimia Fakultas MIPA Universitas Padjajaran Bandung, Jawa Barat. Data ditabulasi menggunakan program Microsoft Excel, selanjutnya dianalisis menggunakan ragam ANOVA dari rancangan acak lengkap (RAL) dan uji jarak berganda Duncan's.

\section{HASIL DAN PEMBAHASAN}

Hasil penelitian secara umum menunjukkan bahwa rata-rata bobot badan akhir (umur 8 minggu) yang dicapai itik Mojosari jantan selama penelitian adalah 1676,96 g. Rata - rata berat karkas yang dicapai itik Mojosari jantan adalah 1163,58 g. Data hasil penelitian pengaruh penambahan betain dalam pakan rendah metionin terhadap kualitas karkas pada itik Mojosari jantan yang meliputi persentase karkas, persentase dada dan paha, persentase lemak abdominal dan kandungan kolesterol daging dapat dilihat pada Tabel 3.

Tabel 3. Pengaruh penambahan betain dalam pakan rendah metionin terhadap kualitas internal karkas pada itik Mojosari jantan

\begin{tabular}{cccccc}
\hline Perlakuan & $\begin{array}{c}\text { Persentase } \\
\text { karkas } \\
(\%)\end{array}$ & $\begin{array}{c}\text { Persentase } \\
\text { dada } \\
(\%)\end{array}$ & $\begin{array}{c}\text { Persentase } \\
\text { paha } \\
(\%)\end{array}$ & $\begin{array}{c}\text { Lemak } \\
\text { abdominal } \\
(\%)\end{array}$ & $\begin{array}{c}\text { Kolesterol } \\
\text { daging } \\
(\mathrm{mg} / 100 \mathrm{~g})\end{array}$ \\
\hline P0 & $67,84 \pm 1,16^{\mathrm{a}}$ & $24,87 \pm 5,70^{\mathrm{a}}$ & $17,03 \pm 2,70^{\mathrm{a}}$ & $1,08 \pm 0,25$ & $188,42 \pm 0,75$ \\
P1 & $67,65 \pm 2,49^{\mathrm{a}}$ & $28,45 \pm 3,89^{\mathrm{b}}$ & $18,99 \pm 1,74^{\mathrm{b}}$ & $0,82 \pm 0,25$ & $188,14 \pm 0,67$ \\
P2 & $68,28 \pm 3,86^{\mathrm{a}}$ & $22,25 \pm 4,14^{\mathrm{a}}$ & $16,30 \pm 2,31^{\mathrm{a}}$ & $0,81 \pm 0,16$ & $187,85 \pm 0,73$ \\
P3 & $72,00 \pm 2,83^{\mathrm{b}}$ & $30,37 \pm 2,83^{\mathrm{b}}$ & $19,89 \pm 1,33^{\mathrm{b}}$ & $0,79 \pm 0,11$ & $187,93 \pm 0,66$
\end{tabular}

Keterangan : Superskrip yang berbeda pada kolom yang sama menunjukkan pengaruh yang nyata $(\mathrm{P}<0,05)$

\section{Pengaruh perlakuan terhadap persentase karkas}

Tabel 3 menunjukkan bahwa persentase karkas terendah $(67,84 \pm 1,16 \%)$ terjadi pada perlakuan
P0, sedangkan persentase karkas tertinggi $(72,00 \pm 2,83 \%)$ terjadi pada P3 dengan pemberian betain $0,3 \%$ pada pakan. Hasil penelitian Sudiyono dan Purwatri (2007) menyatakan bahwa rata- 
rata persentase karkas itik lokal jantan umur 10 minggu adalah 52,93-54,78\%. Persentase karkas yang paling tinggi $(75,87 \pm 104,66 \%)$ terdapat pada P3, sedangkan hasil persentase karkas terendah $(67,84 \pm 3,15 \%)$ terdapat pada P1. Hasil rata-rata persentase karkas penelitian ini lebih tinggi dari hasil penelitian Sudiyono dan Purwati (2007) yaitu $67,84-72,00 \%$. Hal ini disebabkan pakan yang digunakan berbeda dan adanya pengaruh pemberian betain yang dapat meningkatkan karkas serta kondisi ternak yang menunjang pertumbuhannya. Perbedaan pertambahan bobot badan tersebut sangat berkaitan dengan konsumsi pakan, dukungan dari peningkatan daya cerna zat makanan dari perlakuan penambahan betain pada pakan rendah metionin. Hal ini diduga karena betain tidak terserap secara maksimal dalam tubuh ternak.

Hasil analisis statistik menunjukkan bahwa penggunaan betain memberikan pengaruh yang berbeda nyata $(\mathrm{P}<0,05)$ terhadap persentase karkas. Menurut Harms dan Rusell (2002), betain merupakan osmolit potensial karena mempunyai fungsi osmotik bagi sel epitel maupun mikroflora saluran pencernaan, sehingga betain berpotensi meningkatkan kecernaan beberapa zat makanan. Disamping itu, fungsinya sebagai donor gugus metil yang dapat memenuhi kebutuhan gugus metil bagi ternak serta mengacu pada metabolisme lemak dan protein didalam tubuh, sehingga memberikan perspektif dalam menghasilkan karkas dengan tingkat lemak yang lebih rendah. Selain berpotensi menurunkan lemak, betain dapat meningkatkan sintesis protein yang berguna untuk meningkatkan persentase karkas. Hasil penelitian menunjukkan bahwa betain dapat bekerja secara maksimal dan meningkatkan persentase karkas.

\section{Pengaruh perlakuan terhadap persentase deposisi daging dada}

Hasil analisis statistik menunjukkan bahwa penggunaan betain terhadap persentase daging dada memberikan perbedaan pengaruh yang nyata $(\mathrm{P}<0,01)$ terhadap persentase deposisi daging dada. Hasil perhitungan statistik pada perlakuan P3 menunjukkan bahwa deposisi daging dada memiliki bobot yang lebih tinggi $(30,37 \pm 2,8 \%)$ dibandingkan dengan perlakuan yang lain. Hal tersebut diduga akibat pemberian betain yang sudah seimbang dengan kondisi ternak yang mana berpengaruh terhadap peningkatan nafsu makan serta menimbulkan pengaruh terhadap performan ternak itik Mojosari jantan. Menurut Subhan dkk (2010), rata-rata persentase dada itik jantan pada perlakuan pakan yang diberi sagu kukus dan tepung keong mas sebagai pengganti jagung kuning secara berurutan 0,15 , 30, dan $40 \%$ dari pakan adalah 27,60 \pm $0,94 \% ; 27,98 \pm 0,77 \% ; 27,02 \pm 2,47 \%$; dan $27,77 \pm 1,24 \%$. Hasil analisis statistik baik pengaruh pakan maupun bangsa tidak berbeda nyata terhadap persentase dada itik, walaupun demikian dari segi bangsa, itik Mojosari Alabio memiliki performan yang lebih tinggi dibandingkan dengan persentase kedua bangsa yang lain.

$$
\text { Hasil analisis tertinggi }
$$
$(30,37 \pm 2,8 \%)$ terdapat pada perlakuan P3 dari bobot hidup dengan pemberian betain sebanyak $0,3 \%$ dari pakan. Perlakuan ini memberikan hasil yang terbaik. Persentase deposisi daging dada terendah $(22,25 \pm 4,14 \%)$ pada $\mathrm{P} 2$ dengan penambahan $0,2 \%$ betain dari pakan. Seharusnya yang diharapkan didalam penelitian ini adalah perlakuan kontrol (P0) menghasilkan persentase terendah, tetapi hasil penelitian menunjukkan 
bahwa perlakuan terendah terdapat pada P2. Hal ini sulit dijelaskan karena kemungkinan merupakan faktor genetik yang sulit diprediksi walaupun dari jenis itik yang sama (Itik Mojosari). Bobot dada yang tinggi memungkinkan itik akan menghasilkan persentase karkas yang tinggi (Hadiwiyoto, 1992). Menurut Soeparno (2005), pertumbuhan dipengaruhi oleh genetik, jenis kelamin, umur dan lingkungan. Hasil penelitian pengaruh pemberian betain pada pakan rendah metionin ini tidak jauh berbeda dengan hasil dari penelitian yang dilaporkan Sudiyono dan Purwatri (2007) bahwa persentase dada itik lokal jantan berkisar antara 26-29\%.

\section{Pengaruh perlakuan terhadap persentase daging paha \\ Hasil analisis statistik}

menunjukkan bahwa penggunaan betain memberikan perbedaan pengaruh yang nyata $(\mathrm{P}<0,05)$ terhadap persentase paha dimana perlakuan P3 memiliki persentase tertinggi $(19,89 \pm 1,3 \%)$ dan persentase terendah $(16,30 \pm 2,3 \%)$ terdapat pada perlakuan P2. Bobot paha secara berurutan mulai dari yang terendah hingga yang tertinggi adalah 16,30 g (P2); 17,03 g (P0); 18,99 g (P1); 19,89 g (P3). Bagian dada dan paha adalah salah satu bagian karkas yang memiliki nilai ekonomis yang tinggi (Omojola, 2007). Menurut Armissaputri dkk (2013), persentase paha itik Mojosari jantan adalah 13,03 $\pm 1,20 \%$ dengan bobot paha $161,58 \pm 18,11 \mathrm{~g}$. Setiyanto (2005) menyatakan bahwa persentase paha itik Alabio jantan umur 10 minggu dengan penambahan tepung daun beluntas $0,5 \%$ adalah sebesar $23,53 \%$ sementara persentase paha itik Tegal dengan penambahan tepung daun beluntas $0,5 \%$ sebesar $26,44 \%$.

Hasil penelitian ini dapat dikatakan bahwa perlakuan yang terbaik adalah pemberian betain dengan kadar
0,3\% dari pakan rendah metionin yang dapat meningkatkan persentase karkas bagian paha secara nyata. Berbagai argumentasi untuk menjelaskan perbedaan efektivitas betain dalam mengganti metionin seperti tersebut diatas masih belum jelas karena beberapa penelitian dilakukan pada kondisi yang berbeda, misalnya adanya cekaman koksidiosis yang dapat meningkatkan respon terhadap betain (Matthews et al, 1998).

\section{Pengaruh perlakuan terhadap persentase lemak abdominal \\ Hasil analisis statistik} menunjukkan bahwa penggunaan betain tidak memberikan pengaruh yang nyata $(\mathrm{P}<0,05)$ terhadap persentase lemak abdominal, sehingga antara perlakuan kontrol dan perlakuan yang diberi betain tidak terdapat perbedaan. Hal ini dikarenakan kandungan energi dan protein pada pakan perlakuan memiliki kandungan nutrisi yang sama sehingga menghasilkan perlemakan yang sama pula.

Wahyu (2004) menyatakan bahwa komposisi kandungan nutrisi pada pakan merupakan faktor yang mempengaruhi banyaknya kandungan lemak pada tubuh ternak. Hal tersebut dapat terjadi karena berlebihnya energi yang dikonsumsi oleh unggas tersebut. Adanya penurunan bobot lemak abdominal merupakan hal yang sangat menguntungkan karena proses tersebut dapat memperbaiki kualitas karkas dengan menghasilkan daging yang disebut daging rendah lemak (Sanz et al, 2000 dalam Nur, 2006). Secara statistik hasil tersebut belum memberikan perbedaan yang nyata.

Tabel 3 memperlihatkan terjadi penurunan lemak abdominal sebesar $0,79 \pm 0,11 \%$ pada perlakuan P3 atau pada pakan yang diberi penambahan betain, sedangkan pada perlakuan 
control menghasilkan lemak abdominal sangat tinggi $(1,08 \pm 0,25 \%)$. Hasil penelitian Amiruddin dkk (2011) menyatakan bahwa pengaruh lisin dalam menurunkan lemak abdominal yang merupakan salah satu bagian dari komposisi non karkas tidak memberikan dampak perubahan persentase karkas yang besar karena jumlah yang diberikan dari persentase lemak abdominal cukup kecil (maksimal 0,73\% dari bobot potong) pada itik lokal jantan. Penelitian Sudiyono dan Purwatri (2007) menyatakan bahwa kandungan lemak abdominal pada itik lokal jantan umur 10 minggu yang diberi penambahan enzim mempunyai rata-rata $1,35-1,74 \%$. Itik lokal jantan hasil penelitian memiliki persentase lemak abdominal yang berbeda karena adanya perbedaan strain, pakan dan lingkungan yang digunakan. Soeparno (2005) menyatakan bahwa persentase lemak abdominal dipengaruhi umur, jenis kelamin, spesies dan pakan yang dikonsumsi.

\section{Pengaruh perlakuan terhadap kandungan kolesterol daging dada}

Pengaruh penggunaan betain dalam pakan terhadap kolesterol daging dada itik Mojosari jantan dapat dilihat pada Tabel 3. Kandungan kolesterol daging dada itik Mojosari jantan yang terendah $(187,85 \pm 0,73 \mathrm{mg} / 100 \mathrm{~g})$ terjadi pada perlakuan $\mathrm{P} 2$ dengan pemberian betain $0,2 \%$ dari pakan dan kandungan kolesterol daging dada yang tertinggi $(188,42 \pm 0,75 \mathrm{mg} / 100 \mathrm{~g})$ terdapat pada perlakuan P0 yang merupakan perlakuan kontrol dari penelitian.

Hasil perhitungan analisis statistik menunjukkan bahwa penggunaan betain terhadap kandungan kolesterol daging dada itik Mojosari jantan tidak berbeda nyata $(\mathrm{P}<0,05)$. Dengan demikian pakan kontrol dengan pakan perlakuan yang diberi betain secara perhitungan statistik tidak memberikan perbedaan pengaruh yang nyata. Menurut hasil penelitian Sobri dkk (2006), pengaruh sumber energi dan asam lemak ransum terhadap perlemakan tubuh itik jantan di daerah tropik menunjukkan bahwa kolesterol daging dari itik Mojosari jantan umur 9 minggu rata-rata 109,44-104,91 mg/100 g. Pemberian pakan butiran menunjukkan kadar lemak daging yang meningkat sebagai akibat dari kelebihan gula darah yang dikonversi dalam bentuk lemak yang berpengaruh pada peningkatan lemak dan kolesterol yang dideposisikan kedalam daging dan jaringan dibawah kulit pada unggas. Hasil penelitian kadar kolesterol terendah $(187,85 \pm 0,73)$ terdapat pada $\mathrm{P} 2$ dengan pemberian betain $0,2 \%$. Hasil penelitian Naber (1976) dalam Joseph (2002) menyatakan bahwa hampir $2 / 3$ bagian kolesterol disintesa oleh tubuh ternak, sementara 1/3 bagian diperoleh karena perlakuan pakan dan tinggi rendahnya kolesterol dalam tubuh juga dipengaruhi pakan yang dikonsumsi. Langkah untuk menurunkan kadar kolesterol dengan cara meningkatkan konsumsi serat kasar, dimana serat kasar ini dapat meningkatkan produksi empedu dan mengeliminasi ke usus untuk disekresi (Mangkusitepoe, 1992).

\section{KESIMPULAN}

Penggunaan betain dalam pakan rendah metionin dapat meningkatkan persentase karkas, persentase deposisi daging dada dan paha, serta menurunkan persentase lemak abdominal namun tidak mempengaruhi kandungan kolesterol daging dada pada itik Mojosari jantan. Level penggunaan betain sebesar $0,3 \%$ dari pakan adalah hasil terbaik terhadap kualitas karkas itik Mojosari jantan ditinjau dari persentase karkas, persentase deposisi daging dada dan paha serta menurunkan persentase lemak abdominal. 


\section{DAFTAR PUSTAKA}

Amiruddin, B. N. K., Sudiyono dan Ratriyanto, A. 2011. Pengaruh suplementasi lisin terhadap karakteristik karkas itik lokal jantan umur sepuluh minggu. Fakultas Pertanian Universitas Sebelas Maret Sains Peternakan Vol. 9 (1), Maret 2011: 15-19.

Anggorodi, H. R. 1995. Nutrisi aneka ternak unggas. PT Gramedia Pustaka Utama. Jakarta.

Armissaputri, N. K., Ismoyowati, Mugiyono. S. 2013. Perbedaan bobot dan persentase bagianbagian karkas dan non karkas pada itik lokal (Anas plathyrincos) dan itik manila (Cairina moschata). Fakultas Peternakan Universitas Jenderal Soedirman. Purwokerto.

Hadiwiyoto, S. 1992. Kimia dan teknologi daging unggas. Pusat Antar Universitas Pangan dan Gizi Universitas Gadjah Mada. Yogyakarta.

Harms, R. H., and G, B. Russell. 2002. Betaine does not improve performance of laying 18 Sains Peternakan Vol. 11 (1), 2013 hens when the diet contains adequate choline. Poultry Science. 81:99101.

Mangkusitepoe. 1992. Kolesterol fobia keterkaitan dengan penyakit jantung. Gramedia Pustaka Utama. Jakarta.

Matthews, J. O., L, L. Southern., J, E. Pontif., A. D. Higbie and T. D. Bidner. 1998. Interactive effects of betaine, crude protein, and net energy in finishing pigs. J. Anim. Sci. 76: $2444-2455$.

Naber, E. C. 1976. The cholesterol problem, the egg and lipid metabolism in the laying hen. Poultry Sci. 55: 14. Dalam Joseph, G., H, T. Uhi., Rukmiasih, I., Wahyuni, S., Y. Randa., H. Hafid, dan A. Parakkasi. 2002. Status kolestrol itik Mandalung dengan pemberian serat kasar dan vitamin E. Seminar Nasional Teknologi Peternakan dan Veteriner: 265267.

Omojola, A. B. 2007. Carcass and organoleptic characteristic of duck meat as influenced by breed and sex. International Journal of Poul. Sci 6 (5): 329-334.

Ratriyanto, A., Indreswari, R. dan Sudiyono. 2012. Efektivitas betain pada pakan ayam broiler rendah metionin berdasarkan parameter bobot badan dan karkas. Jurusan Peternakan, Fakultas Pertanian Universitas Sebelas Maret.

Sanz, M., A, Flores and C. J Lopez-Bote. 2000. The metabolic use of energy from dietary fat in broiler is affected by fatty acid saturation. Br. Poutlry Sci. 41 (1):61-68. Dalam Nur, I. F. 2006. Persentase bobot karkas, lemak abdomen dan organ dalam ayam broiler dengan pemberian silase pakan komersial. Skripsi. Program Studi Teknologi Produksi Ternak. Fakultas Peternakan Institut Pertanian Bogor. Bogor.

Schable, P. J. 2004. Poultry feed and nutrition. Departement of poultry series, Michigan State University East Lansing, Michigan. 198 198.

Setiyanto, R. D. 2005. Persentase bagian-bagian tubuh itik jantan lokal umur 10 minggu dengan penambahan tepung daun beluntas (Pluchea Indica L.) dalam pakan. Skripsi. Departemen Ilmu Produksi dan Teknologi Peternakan. Fakultas Peternakan, Institut Pertanian Bogor. Bogor.

Sobri, M., Supadmo, dan Wibowo, A. 2006. Pengaruh sumber energi dan asam lemak ransum terhadap 
perlemakan tubuh itik jantan di daerah tropik. J. Indon. Trop. Anim. Agric. 31 March 2006. Fakultas Peternakan dan Perikanan Universitas Muhammadiyah Malang, dan Fakultas Peternakan Universitas Gadjah Mada, Yogyakarta.

Soeparno. 2005. Ilmu dan teknologi daging. Cetakan keempat. Gadjah Mada University Press. Yogyakarta.

Subhan A., Yuwanta T. dan Sidadolog, J. H. P. 2010. Pengaruh kombinasi sagu kukus (Metroxylon Spp) dan tepung keong mas (Pomacea Spp) sebagai pengganti jagung kuning terhadap penampilan itik jantan Alabio, Mojosari, dan hasil persilangannya. Buletin Peternakan Vol. 34 (1): 30-37, Februari 2010. Balai Pengkajian Teknologi Pertanian (BPTP). Kalimantan Selatan. ISSN 01264400 .
Sudiyono dan Purwatri, T. H. 2007. Pengaruh penambahan enzim dalam ransum terhadap persentase karkas dan bagian-bagian karkas itik lokal jantan. Fakultas Pertanian Universitas Sebelas Maret, Surakarta.

Sumiati, Y., Arius dan R, Mutia. 2005. Persentase karkas dan non-karkas itik Mandalung yang diberi tepung singkong (Manihot) dalam ransumnya. hlm. 281-288. Prosiding Lokakarya Nasional Unggas Air II, Ciawi, 16-17 November 2005.

Wahyu, J. 2004. Ilmu nutrisi unggas. Edisi Ke-5. Gajah Mada University Press. Yogyakarta.

Widiastuti, R. 2001. Pengaruh penambahan ampas tahu fermentasi dalam pakan terhadap karkas dan perlemakan. Skripsi. Fakultas Peternakan. Universitas Gadjah Mada. Yogyakarta. 